Working Paper97-13 / Document de travail 97-13

What Does Downward Nominal-Wage Rigidity Imply for Monetary Policy?

by

Bank of Canada Banque du Canada 
ISSN 1192-5434

ISBN 0-662-25874-6

Printed in Canada on recycled paper 
Bank of Canada Working Paper 97-13

June 1997

\title{
What Does Downward Nominal-Wage Rigidity Imply for Monetary Policy?
}

\author{
by \\ Seamus Hogan \\ Research Department \\ 5-West Tower, Bank of Canada \\ 234 Wellington Street, Ottawa, ON K1A OG9 \\ shogan@bank-banque-canada.ca
}

The views expressed in this paper are those of the author and not necessarily those of the Bank of Canada. Correspondence concerning this paper should be addressed to Seamus Hogan. 


\section{Acknowledgments}

I would like to thank Phillip Bagnoli, Allen Crawford, Irene Ip, David Longworth, Tiff Macklem, Brian O'Reilly, and Chris Ragan for their many helpful comments. I remain, however, solely responsible for the paper's content and for any remaining errors in the text. 


\begin{abstract}
A recent paper has suggested there might be a trade-off between inflation and unemployment at low inflation rates and this has led some economists to recommend that Canada increase its inflation rate. Underlying this view is the idea that, because firms are reluctant to cut workers' nominal wages, a moderate amount of inflation can be used to facilitate needed reductions in real wages. This paper discusses the link from downward nominal-wage rigidity to unemployment and considers some of the issues that need to be addressed to determine whether a change in Canada's monetary policy is warranted.
\end{abstract}

\title{
Résumé
}

Un article publié récemment avance une hypothèse susceptible d'expliquer l'existence d'un arbitrage entre le chômage et l'inflation lorsque celle-ci est faible. Certains économistes en ont conclu que les autorités canadiennes devraient permettre une hausse du taux d'inflation. Selon l'hypothèse avancée, comme les entreprises hésitent à réduire les salaires nominaux, la présence d'une inflation modérée pourrait faciliter la diminution des salaires réels quand cela est nécessaire. L'auteur de l'étude analyse le lien entre la rigidité à la baisse des salaires nominaux et le chômage et examine certaines des questions qui doivent être réglées afin d'établir si une modification de la politique monétaire est justifiée. 



\section{Contents}

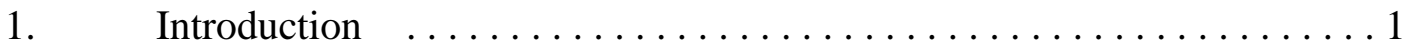

2. The Akerlof, Dickens, and Perry model $\ldots \ldots \ldots \ldots \ldots \ldots$

3. Downward nominal-wage rigidity $\ldots \ldots \ldots \ldots \ldots \ldots \ldots \ldots \ldots \ldots \ldots \ldots \ldots$

4. The link between inflation and real wages $\ldots \ldots \ldots \ldots \ldots \ldots$

5. The link between real wages and unemployment $\ldots \ldots \ldots \ldots \ldots 12$

$5.1 \quad$ Firms' response to higher wages $\ldots \ldots \ldots \ldots \ldots \ldots \ldots$

5.2 Workers' response to higher wages $\ldots \ldots \ldots \ldots \ldots \ldots$

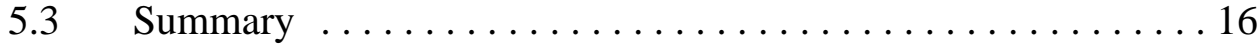

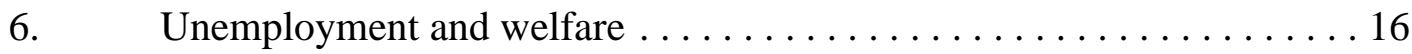

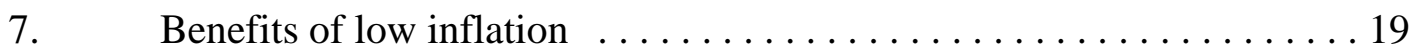

7.1 Psychological costs of inflation . . . . . . . . . . . . . 19

7.2 Psychological costs and downward nominal-wage rigidity . . . . 21

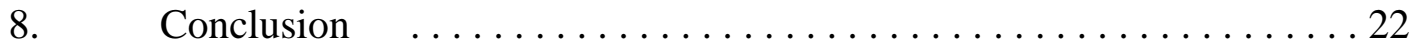

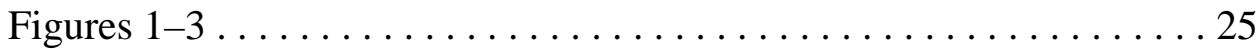

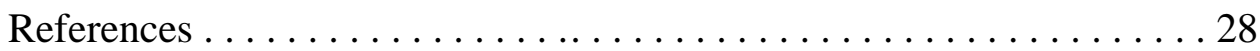





\section{Introduction}

In the late 1980s, both Canada and the United States experienced moderate levels of inflation of approximately 3 to 5 per cent, down from the relatively high levels that both countries experienced at the end of the previous decade. In the 1990s, Canada has followed a more aggressive policy towards inflation than has the United States. Specifically, in February 1991, the Governor of the Bank of Canada and the Finance Minister announced that Canada would seek "price stability" and formalized this objective in joint announcements that the Bank will exercise monetary policy to target inflation within a specified range. The current "joint statement on monetary policy objectives" specifies a target range for inflation of 1 to 3 per cent from 1995 to the end of 1998. Before the end of 1998, when the current joint statement expires, Canadian policymakers will need to decide whether a change in the target range for inflation is warranted.

In the past year, Canada's policy has come under public attack by two prominent economists: Pierre Fortin (1996a) in an article in the Globe and Mail that drew on his presidential address to the Canadian Economics Association (Fortin, 1996b), and Paul Krugman (1996) in an article in the Economist. Both economists believe that Canada should not be striving for so low a rate of inflation. Instead, they favour the approach taken by the Federal Reserve in the United States. The Federal Reserve does not have an explicit inflation target but has maintained U.S. inflation at around 3 per cent. Recently, the U.S. congress considered a bill (the Economic Growth and Price Stability Act, 1995) that would have given the Federal Reserve a low-inflation mandate, similar to that of the Bank of Canada, but the bill was not passed.

The debate in both countries whether their central banks should strive to keep inflation at very low levels concerns the long- and short-run relationships between inflation on the one hand and unemployment and output on the other. The nature of this relationship has been one of the most important questions in macroeconomics for several decades and one on which the view of the profession has evolved considerably over time in response to new research and the changing levels

of inflation experienced in many countries. Currently, the mainstream view of the relationship between inflation and unemployment and growth can be summarized as follows: 
1. In the long run, there is no relationship between inflation and unemployment. Thus, the maintenance of low inflation does not come at the cost of a permanently higher unemployment rate.

2. In the long run, the maintenance of low and stable inflation generates benefits to productivity. Therefore, targeting low inflation will produce higher output over time.

3. In the short run, however, there is a trade-off between inflation and unemployment as inflation can normally be reduced only at the expense of a temporary increase in unemployment and a corresponding temporary decline in output (or at least a slowdown in output growth).

According to this view, the desirability of reducing inflation from moderate to low levels, as Canada did at the start of this decade, depends on whether the long-run benefits of maintaining low and stable inflation outweigh the short-run costs of the initial disinflation. The mainstream view regards the costs of achieving low inflation as transitional rather than permanent and also suggests that, once low and stable inflation is achieved, the optimal policy is to maintain it at that level. Within the mainstream view, there is a historical debate whether Canada's policy of disinflation in the early 1990s was desirable. However, as Canada has already incurred the short-run transitional costs, both sides in that debate would regard it as worthwhile for Canada now to maintain inflation at its current low level and enjoy the long-run benefits.

It is this aspect of the mainstream view that Krugman and Fortin challenge. Drawing on a recent paper by Akerlof, Dickens, and Perry (1996), Krugman and Fortin suggest that, contrary to the conventional wisdom of Point 1 above, there is a long-run negative relationship between inflation and unemployment. Therefore, low inflation can be achieved only at the expense of permanently higher unemployment and lower output. ${ }^{1}$

\footnotetext{
1. Throughout this paper, the term "low inflation" is used to refer to rates of between 0 and 3 per cent, and "moderate inflation" for rates of around 3 to 5 per cent.
} 
Akerlof, Dickens, and Perry (hereafter, ADP) have formally modelled an idea that has often been conjectured by macroeconomists, most famously by James Tobin (1972) in his presidential address to the American Economic Association in 1971. This idea is based on the assumption that, for psychological reasons, workers are very reluctant to accept cuts to their nominal wages but will accept real-wage cuts if inflation erodes the value of a given nominal wage. In Tobin's view, the maintenance of high levels of employment will often require cuts in the real wages of workers in some sectors of the economy. His argument is that "downward nominal-wage rigidity" implies that these cuts are easier to achieve when there is moderate inflation than when inflation is low. As a result, there will be a permanent trade-off between inflation and unemployment.

The idea that downward nominal-wage rigidity is a pervasive feature of labour markets is controversial as it seems to suggest that workers suffer from "money illusion"- that is, they do not realize the effect that inflation has in reducing the real value of their wages and so can be fooled by inflation into accepting real-wage cuts that they would not otherwise accept. In the absence of compelling evidence to the contrary, economists are generally reluctant to accept theories that depend on people behaving in a seemingly irrational way. Studies that have looked for evidence of downward nominal-wage rigidity, moreover, have produced inconclusive results. This perhaps explains why Tobin's view of a trade-off between inflation and unemployment at low rates of inflation has not been widely accepted by macroeconomists.

ADP's paper therefore represents a major challenge to the profession. ADP provide evidence casting some doubt on the validity of previous studies that have found little empirical support for downward nominal-wage rigidity. They then develop Tobin's intuition further by building a model to show how downward nominal-wage rigidity might generate a negative long-run relationship between inflation and unemployment.

Although ADP provide reasons for being cautious in accepting some of the evidence against downward nominal-wage rigidity, the evidence in favour is also not conclusive. At this stage, it is still unclear whether such rigidity is a pervasive feature of the U.S. or Canadian economy and much work is likely to be done on this question in the next few years. Even if downward nominal-wage rigidity is shown to be prevalent in Canada, however, it does not automatically follow that it would be desirable for Canada to increase its rate of inflation. There are many other important steps in 
ADP's analysis and each of these needs to be considered carefully in the public debate over what Canada's inflation target should be.

This paper details the key steps in ADP's analysis and discusses some of the theoretical and empirical issues surrounding each one. The paper's main conclusion is that, on the basis of the available evidence, the case is weak for Canada to revise its inflation targets upwards. The main objective of the paper, however, is not to reach a particular conclusion but rather to highlight some of the assumptions underlying Fortin's and Krugman's critique of Canadian monetary policy, and thus to stimulate debate on this issue.

The next section contains a brief summary of the model used by ADP and lists the five main steps linking downward nominal-wage rigidity to a policy conclusion in favour of higher inflation. Sections 3 to 7 then consider each of these steps in turn. Finally, Section 8 discusses some of the policy conclusions for Canada from ADP's analysis.

\section{The Akerlof, Dickens, and Perry model}

ADP describe an economy that is constantly subject to changes that have different effects across firms. In economics terminology, firms are subject to "heterogeneous shocks." At any one time, there are always some firms receiving "positive shocks" (i.e., their profitability is rising and they are seeking to expand) and other firms receiving "negative shocks" (i.e., their profitability is falling, leading them to contract). Examples of such heterogeneous shocks are changes in consumer tastes that shift demand from some products to others, the discovery of new production processes that lower production costs in particular industries, and changing exposure to competition from foreign firms.

Imagine that wages in this economy are not set in a competitive labour market but by wage bargaining between workers and firms. This has two effects. First, it generates unemployment as a permanent phenomenon in the economy. ADP assume that firms have conventional downward-sloping demand curves for labour. The bargaining power of workers keeps wages higher than would be the case in a competitive labour market, thus pushing firms up their labour demand curves and so restricting the number of jobs in the economy. The second effect of wage bargaining is that the wages paid in any firm will be 
related to its profitability. Thus, the wages paid to workers in high-profit firms will be higher than those paid to equivalent workers in low-profit firms.

As a result of heterogeneous shocks and wage bargaining, there will be a considerable variation across firms in any year in how much the wages paid in each firm have increased from the previous year. Real wages will increase most in firms that have experienced the largest positive shocks to their profitability. More importantly, even if there is general growth in the economy so that most firms face positive shocks, there will always be some firms where negative shocks lead to a reduction in real wages. The constant churning in the economy implied by heterogeneous shocks will also show up in employment, with job creation at expanding firms and job destruction at contracting firms.

Now, imagine that the economy faces downward nominal-wage rigidity: that is, for some reason, the bargaining process that determines wages at each firm will place a wage floor at the current nominal wage so that no worker ever receives a nominal-wage cut. With moderate levels of inflation, this will not impose a constraint on the economy since real wages can be reduced simply by freezing nominal wages and letting inflation erode their real value. When inflation is low, however, downward nominal-wage rigidity restricts the extent to which real wages can fall. As a result, some of the firms that have suffered negative shocks will not be able to lower their real wages by as much as they would have if inflation were at moderate levels; instead, they will reduce the number of their employees by more than they otherwise would have.

This is the source of the negative long-run relationship between inflation and unemployment in ADP's model. It is not necessary that downward nominal-wage rigidity be absolute in the sense that nominal wages can never fall. What is needed is that it be easier to some extent to reduce real wages by inflation than by cutting nominal wages directly.

The description of the economy as being one continuously subjected to heterogeneous shocks is certainly an accurate description of the Canadian and U.S. economies. It is also true that there is variation across firms in the rate of wage increases in any one year, and that there are very high levels of job creation and destruction in both economies each year. ${ }^{2}$ There are other aspects of the

2. ADP cite evidence showing similar variation in wage changes across firms in Canada and the United States. Davis, Haltiwanger, and Schuh (1996) cite two studies from the United States and two from Canada showing that over 10 per cent of all jobs in the two countries are created and a similar number destroyed over the course of a year. 
ADP model, however, for which the empirical basis is less clear. In particular, their analysis that low inflation is undesirable depends on each one of the following five steps:

1. Nominal wages are downwardly rigid.

2. As a result, low inflation produces real wages that are higher on average than when inflation is moderate.

3. These higher average real wages lead to an increase in unemployment.

4. The increase in unemployment generated by low inflation and downward nominalwage rigidity implies a reduction in overall welfare.

5. This cost of higher unemployment is not outweighed by other benefits of low inflation.

Before concluding that Canada should increase the range within which it targets inflation, each of these five steps needs to be carefully justified. The remainder of this paper considers some of the theoretical and empirical issues surrounding each of the five. The main issue addressed in this paper is not whether downward nominal-wage rigidity is pervasive in the economy, but rather the implications for monetary policy if it is. We therefore concentrate on Steps 2 to 5. First, however, it will be useful to summarize the existing evidence for downward nominal-wage rigidity.

\section{Downward nominal-wage rigidity}

Studies examining downward nominal-wage rigidity fall into two broad categories. First, there are sociological studies that survey workers and employers directly about their attitudes to nominal-wage cuts. Second, there are studies that examine data of year-on-year changes in nominal wages to see if there is an abnormal concentration at zero.

Sociological studies include Kahneman, Knetsch, and Thaler (1986), Blinder and Choi (1990), and Bewley (1995). Collectively, these studies report that perceived fairness is an issue in wage determination, and that there is a psychological difference between the way workers and firms view nominal-wage cuts and equivalent inflation-induced realwage cuts. Surveys of attitudes, however, are often unreliable measures of actual 
behaviour, since responses to questions such as, "Do you consider the following situation fair?" or "How would you react in the following hypothetical circumstance?" are sensitive to the context in which the respondent assumes that the circumstances would arise. Therefore, although the sociological studies provide a sense of workers' and firms' attitudes, it is important to supplement these with direct evidence taken from observed wage changes before drawing strong conclusions about downward nominal-wage rigidity.

A number of recent studies have looked at U.S. data of wage changes for evidence that nominal-wage reductions are rarer than one would expect if nominal wages were no less flexible downwards than upwards. The conclusions drawn by the authors of these studies are mixed: Kahn (1995) and ADP find evidence in favour of downward nominal-wage rigidity; McLaughlin (1994), Lebow, Stockton, and Wascher (1995) and Card and Hyslop (1996) find at most only weak support. These differences are due in part to differences in the source of the data. For instance, ADP believe that there is considerable measurement error in the data used by the other authors that leads them to overestimate the extent of nominal-wage reductions.

The main problem, however, is one of interpretation of the data. For instance, in the period during which the data in the above studies were collected, the United States did not experience the very low rates of inflation of 0 to 2 per cent at which ADP suggest the long-run trade-off between inflation and unemployment occurs. This limits the extent to which these data can either support or reject ADP's conclusions. To draw inferences from data collected during periods of moderate inflation about the extent to which downward nominal-wage rigidity would exist with low inflation, one has to assume that firms would not adapt their wage-setting behaviour to the new environment. This assumption is certainly debatable. When inflation is 3 per cent, a firm that wished to reduce its real wage by 6 per cent would not need to lower its nominal wage: it could simply impose a wage freeze for two years. If inflation were 0 per cent, it would not have this option and so would likely be more willing to cut nominal wages. Thus, the downward nominalwage rigidity that would appear in the data when inflation was 3 per cent could easily disappear at lower rates. (This possibility is discussed in Ball and Mankiw 1994.)

Canada's recent experience with inflation rates below 3 per cent can potentially provide a better source of information. Even this information needs to be treated cautiously, however, since the Canadian economy has been subjected to a number of changes in recent years that make 
comparisons with earlier years difficult. These include the phasing in of free trade, the efforts of both federal and provincial governments to deal with their fiscal deficits, and the political situation in Quebec.

Figures 1 to 3 illustrate some of the problems encountered when trying to determine whether wages are affected by downward nominal-wage rigidity. Figure 1 shows the distributions over two 4-year periods of nominal-wage changes in Canadian private sector collective-bargaining contracts. In each graph, the horizontal axis shows the percentage increase in nominal wages and the vertical axis shows the percentage of all contracts with that increase. These data cover union-based contracts at Canadian enterprises with at least 500 employees, and so represent only about 10 per cent of the private sector nonagricultural paid work force; however, they do describe the sector that most resembles ADP's model of wage bargaining.

Figure 1(a) shows the distribution of nominal-wage settlements in the moderateinflation period of 1984-87 when inflation in the consumer price index (CPI) ranged from 3.8 to 4.4 per cent. In this graph, there is a large "spike" in the distribution at zero: that is, the proportion of wage settlements with no change in nominal wages is very large (7.4 per cent) compared with the proportion involving small increases or small decreases. This spike does suggest a degree of rigidity in nominal wages during the period of moderate inflation.

Figure 1(b) shows the period 1992-95, a stage in the business cycle equivalent to the earlier period but one in which inflation was low (CPI inflation ranged from 0.2 to 2.1 per cent over this period). If there were no nominal-wage rigidity, we might expect the second graph to look just like the first except shifted to the left to reflect the fact that nominal-wage increases are lower when inflation is lower. If, on the other hand, there is pervasive downward nominal-wage rigidity, then we would expect to see the left part of the distribution pulled to the centre with a large spike at zero as firms impose wage freezes rather than small cuts in nominal wages. In fact, neither is the case. The distribution is shifted to the left but there is little evidence of truncation of the distribution at zero: there is only a small increase in the spike at zero (with now 11.9 per cent of contracts involving 
wage freezes), ${ }^{3}$ and, more importantly, the right side of the distribution is pulled to the centre by more than the left side. In short, the pattern of wage settlements does appear different between the two periods, but it is not apparent that the difference is attributable to downward nominal-wage rigidity.

Rather than trying to compare the two distributions, can we infer downward nominal-wage rigidity directly from the large proportion of nominal-wage freezes in both periods? As noted above, this spike at zero suggests that there is some rigidity in nominal wages. It does not, however, imply that the rigidity is specifically downwards: instead, it might be due to the presence of what are termed "menu costs" (see Mankiw 1985). This describes any situation in which there is a cost to changing a nominal wage or price, in any direction: that is, menu costs generate symmetrical nominal-wage rigidity. In Figure 1, the unusually large number of wage freezes seems to have come at the expense of small wage increases as well as decreases suggesting that menu costs played at least some role in producing the spike at zero.

To illustrate the difficulty in distinguishing between downward nominal-wage rigidity and menu costs, Figures 2 and 3 conjecture what the distribution of nominal-wage changes would have looked like if there were no nominal rigidity. Figure 2 conjectures that the spike in Figure 1 is due entirely to downward rigidity, and Figure 3 conjectures that it is due to symmetrical rigidity. Specifically, in Figure 2, it is assumed that two-thirds of the wage freezes would have been nominal- wage cuts of up to 1 per cent (that is, increases of between -1 per cent and 0 per cent) and that the remaining third would have been cuts of between 1 per cent and 2 per cent. Figure 3 does the same thing, except that it allocates the wage freezes in Figure 1 equally to increases and decreases. To be confident in attributing the spike at zero in Figure 1 to downward rigidity, we would have to be able to reject the hypothetical distributions in Figure 3 as being the true

3. Fortin (1996b) gives a value of 47 per cent of wage settlements being wage freezes over the three-year period 199294. This value is also cited by ADP and Krugman. The large difference between Fortin's value and the 11.9 per cent shown in Figure 1(b) arises for two reasons other than the slight difference in the period covered. First, Fortin includes both public and private sector contracts and excludes contracts that did not contain a cost-of-livingadjustment (COLA) provision. The data here are only for private sector contracts, since it is to the private sector that ADP's model applies, but they include both COLA and non-COLA contracts. Second, the wage increase in multiyear contracts is defined here as the average annual percentage increase over the lifetime of the contract whereas Fortin considers only the wage change in the first year of the contract. Fortin's definition includes as a wage freeze multi-year contracts in which, perhaps due to delays in negotiating the contract, no increase is paid in the first year but catch-up increases occur in later years. 
underlying distribution before nominal rigidity generated the spike. Casual observation of these graphs does not suggest grounds for such confidence.

Overall, the inherent difficulties in directly observing downward nominal-wage rigidity and the limited experience of low inflation in Canada preclude a definitive answer at this stage whether downward nominal-wage rigidity is an important feature of Canadian labour markets when inflation is low. It is probably fair to say that, although the wagechange data in both Canada and the United States do not provide strong evidence in favour of downward nominal-wage rigidity, neither do they provide a convincing rebuttal of the survey evidence from sociological studies. It is important, therefore, for economists to take seriously the possibility of downward nominal-wage rigidity and to consider its implications for monetary policy. In the remainder of this paper, we turn to the other steps in ADP's analysis linking downward nominal-wage rigidity to a policy conclusion in favour of moderate rather than low inflation.

\section{The link between inflation and real wages}

The Tobin/ADP intuition rests on the idea that inflation can bring an overall decrease in real wages by reducing the importance of downward nominal-wage rigidity. Even if downward nominal-wage rigidity is pervasive in the economy, however, it does not automatically follow that inflation can be used to bring about an overall reduction in average real wages. This depends on how the institutions that determine wages respond to changes in the inflation rate in the presence of downward nominal-wage rigidity.

It will be useful here to distinguish between what we will term "constrained" and "unconstrained" firms. Firms in ADP's model are continually being hit by shocks with the result that, in the absence of downward nominal-wage rigidity, the bargaining process produces increases in the real wage at some firms and decreases at others. Following ADP, we will use the term "notional" wage to describe the wage that would be the result of the bargaining if there were no nominal rigidity. If inflation is low, there will be some firms at which the reduction in notional real wages could only be achieved by a nominal-wage reduction. In the presence of downward nominal-wage rigidity, these firms are constrained in the sense that they cannot reduce real wages by as much as they would if inflation were 
higher. Unconstrained firms are those for which the notional wage has increased or at least has fallen by less than the rate of inflation. These firms can bring about the required change in their notional wage without cutting their nominal wage.

Clearly, if a firm cannot reduce its real wages when inflation is low but would do so if inflation were higher, then higher inflation will lower the real wage at that firm. That is, increasing inflation will lower real wages at those firms that are constrained by downward nominal-wage rigidity. It may also be the case, however, that increasing inflation increases real wages at unconstrained firms.

To see why this might be so, consider a situation where inflation is zero. Imagine a firm is hit by a positive shock that would normally lead to an increase in its real wage but that may last only for one or two years. For instance, the firm may produce an item that is temporarily in fashion or it may enjoy a brief advantage after having discovered a new production process that other firms will imitate after a while. If wages were fully flexible, then this subsequent reversal of fortune would be no problem. In the presence of zero inflation and downward nominal-wage rigidity, however, a firm that allowed its real wage to increase during good times would then find that it could not lower its real wage in subsequent less-favourable times. One might expect workers and firms to take this possibility into account when determining the size of the initial wage increase. Specifically, if the wage-setting process is determined by workers and firms who are forwardlooking, then the real-wage level at unconstrained firms should be lower than would be the case if wages were fully flexible. Furthermore, since downward nominal-wage rigidity imposes less inflexibility on firms when inflation is higher, the real wages at unconstrained firms would be positively related to inflation: that is, higher inflation would lead to higher real wages at unconstrained firms.

This argument can be seen in terms of insurance. The wage floor of downward nominal-wage rigidity provides workers with some insurance against the effect of negative shocks to their firm. That is, it is a form of implicit contract that guarantees that real wages will fall by an amount no greater than the rate of inflation. But wage bargaining requires that, for a given degree of bargaining power, any benefit received in one way will be traded-off against something else. For instance, one sometimes sees union contracts in which wage increases are forgone in return for guarantees of job security. In the case of downward nominal-wage rigidity, the lower the rate of 
inflation, the greater is the insurance against real-wage reductions in the future, and so the greater should be the premium in the form of lower real wages at unconstrained firms.

The above argument was based on the assumption that firms and workers are "forward- looking." It is important to qualify what this means. To say that people are forward-looking does not mean that they have perfect foresight. Rather, it simply means that over time the bargaining process would adjust to the fact that increasing inflation has increased the firm's profitability on average at the expense of average real wages and conversely for decreases in inflation.

It is interesting to interpret the wage-settlement data of Figure 1 in the context of forward-looking behaviour. Recall that the notable thing about the comparison between Figures 1(a) and 1(b) was the fact that the reduction in inflation was associated with a reduction in the variance of wage increases on both sides of the mean. This is consistent with the idea that wage increases in unconstrained firms are reduced when inflation is low to provide a buffer against the possible constraint of downward nominal-wage rigidity at some time in the future. Of course, all the qualifications about the limited inferences that can be drawn from these data that we discussed in Section 3 still apply; but to the extent that these data are suggestive of downward nominal-wage rigidity, they also suggest the presence of forward-looking behaviour in wage setting. In sum, it is difficult to infer from the wage-settlement data that low inflation has led to average real-wage increases in Canada being higher in recent years than they would have been with moderate inflation.

\section{The link between real wages and unemployment}

The third step in the Tobin/ADP framework is that those firms constrained by downward nominal-wage rigidity will respond by reducing employment by more than they would have in the absence of that constraint. This assumes that employment responds negatively to real wages.

Most economists would agree with the proposition that, if something outside a firm's control permanently pushes up its real wage without a corresponding increase in labour productivity, then the firm will eventually respond by reducing the number of workers it 
employs. Note, however, that downward nominal-wage rigidity is a short-run phenomenon. That is, when a firm is hit by a negative shock, downward nominal-wage rigidity imposes a temporary constraint on its wage. This may be because the shock itself is temporary so that a recovery or switch to more profitable products will get the firm back to a situation where it is no longer constrained. Alternatively, if the shock persists, say due to a permanent taste shift of consumers from the firm's products to others that the firm is not equipped to produce, then it may be forced to go out of business. This process of firms exiting from so-called "sunset" industries and new firms entering in "sunrise" industries is an important component of job creation and destruction in

the Canadian and U.S. economies. ${ }^{4}$ A third possibility is suggested by ADP: if a period of low or negative profitability for a firm persists, then the necessity to cut nominal wages to stay in business can overrule any social factors that generate downward nominal-wage rigidity.

The key point here is that downward nominal-wage rigidity will affect a firm only until it returns to profitability, shuts down, or reorganizes its wage contracts. The question to be addressed in this section, then, is whether the higher real wages created by downward nominal-wage rigidity will reduce employment at constrained firms during that initial period.

In the ADP framework, the combination of low inflation and downward nominal-wage rigidity causes a permanent increase in the average level of real wages in the economy, but this arises because there are always some firms in a period of short-run adjustment. Therefore, for there to be a negative link between the higher real wages thus generated and employment, it is necessary that the immediate response of constrained firms to the higher real wages be a reduction in employment. There are a number of reasons for thinking that employment will not respond immediately in this way. Some of these reasons relate to the response of firms to higher wages, and some to the response of workers.

\subsection{Firms' response to higher wages}

The reason for thinking that firms might be slow in reducing their desired level of employment when there is an increase in their real wage arises from what is termed "labour

\footnotetext{
4. Baldwin and Gorecki (1990, Chapter 3) report that between 1970 and 1981 the shutdown of entire establishments accounted for 23 per cent of job destruction in Canadian manufacturing industries, and that the start-up of new establishments accounted for 17 per cent of job creation in those industries. Davis, Haltiwanger, and Schuh (1996) report similar numbers for the United States.
} 
hoarding." This means that, rather than reducing the size of their work force in proportion to the reduction in available productive work brought on by a downturn, firms continue to employ a larger work force than they need at that time. There is considerable evidence that firms do practise labour hoarding, as output is observed to fall by a greater proportion than employment during economic downturns. ${ }^{5}$ A likely explanation for this is that the costs of laying workers off and then hiring and retraining new workers in a subsequent upturn are greater than the cost of maintaining an overstaffed work force during the downturn. Alternatively, if, as suggested by ADP, the reason for downward nominal-wage rigidity is that reductions in nominal wages violate workers' sense of fairness, then employers may be equally reluctant to adjust to the need to pay higher wages by laying off a portion of their work force. Whatever the reason for its existence, labour hoarding suggests that employment need not be as sensitive to short-run movements in real wages as is required in ADP's model.

\subsection{Workers' response to higher wages}

In a labour market where there is a high level of voluntary turnover with workers changing employers or exiting the labour force, a firm can reduce the size of its work force by attrition rather than by laying workers off. In this case, none of the arguments in the previous subsection about why a firm may be reluctant to reduce employment in the face of higher real wages applies. In such labour markets, however, there is another reason why employment may not be negatively related to the real wage in the short run.

To see why, it is useful to distinguish between two types of unemployment. "Demand-constrained" unemployment is the situation in which there are simply fewer jobs available than there are workers seeking to fill them. "Frictional unemployment" results from the fact that workers differ widely both in their skills and experience and in their preferences for non-wage-related job characteristics, while jobs differ widely both in the skills required of the worker and in their characteristics. With such heterogeneity, there is a time-consuming process of finding matches between a worker and a firm so each has the attributes desired by the other. This may be particularly true in times of structural change

5. See, for example, Bernanke and Parkinson (1991). 
when there may be a mismatch between skills currently possessed by workers and those required for the jobs in new industries. Thus, even if there are as many jobs in total as there are workers seeking them, there will be at any time a stock of unemployed workers and vacant jobs still seeking mutually desirable matches.

In ADP's model, all unemployment is demand-constrained due to excessive real wages. In other words, unemployment in their model could be reduced to zero by a general cut in wages. In real-world labour markets, however, we do see the simultaneous existence of large numbers of unemployed workers and large numbers of job vacancies, so frictional unemployment is clearly playing at least some role.

The key point here is that total employment depends not only on the number of job slots created by firms, but also on the proportion of those slots that are vacant. Employment can be increased either by increasing the number of job slots or by reducing the vacancy rate. Although an increase in the real wage at any firm is likely to result in that firm's reducing the number of job slots that it seeks to fill, it may also increase the willingness of workers to accept jobs and reduce their willingness to quit, thus reducing the vacancy rate. In labour markets where worker turnover is high, the vacancy effect is likely to dominate in the short run. This is because workers whose expected tenure at a particular firm is low will care only about wages in the short run whereas firms that have invested in plant and equipment will have a longer-term perspective. As a result, workers are much more likely to respond to short-run changes in wages than are firms.

There is some evidence that this short-run effect does occur in some markets. For instance, Card and Krueger (1995) find evidence that the immediate effect of increases in the minimum wage in some states in the United States has been to increase employment slightly at fast-food firms paying that wage. They also survey time-series studies that suggest a negative relationship between employment and the minimum wage in the longer term. As Card and Krueger point out, the fast-food industry is characterized by very high quit rates. Furthermore, a number of studies have shown that quit rates are negatively related to the wage. ${ }^{6}$ It is quite possible, therefore, that the the counter-intuitive result found by Card and Krueger is a manifestation of the short-run vacancy effect described in the previous paragraph.

\footnotetext{
6. For a survey of such studies, see Devine and Kiefer (1991), Chapter 8.
} 


\subsection{Summary}

The relationship between inflation and unemployment posited by ADP requires that firms reduce employment immediately in response to the temporary increased real wage brought about by downward nominal-wage rigidity. In labour markets with low worker turnover, firms can reduce employment only by laying workers off, but there is some evidence that firms prefer to hoard labour during temporary downturns rather than lay workers off. This does not mean there would be no short-term negative effect on employment in those markets, but the effect is likely to be smaller than would be found in studies looking at the effect on employment of a permanent real-wage increase. In labour markets with high turnover, on the other hand, there are theoretical reasons for thinking that increased real wages might actually have a positive short-term effect on employment, and there is some evidence that this might be the case in at least some low-wage industries.

Overall, the available evidence is mixed whether the aggregate effect across all industries of increased real wages due to downward nominal-wage rigidity would be reduced total employment.

\section{Unemployment and welfare}

Although most people would regard unemployment as a serious social concern, it does not automatically follow from the Tobin/ADP framework that it would be desirable to increase inflation from low to moderate levels. Apart from the question of whether the costs of higher unemployment would be outweighed by benefits of low inflation, it is not clear that the reduced unemployment itself would be desirable in ADP's framework.

Unemployment is a complex phenomenon with many causes, and the impact of unemployment on people's lives depends very much on the form the unemployment takes. Before deriving policy conclusions from a theoretical model that suggests policies to reduce unemployment, it is important to determine two things: exactly why unemployment is undesirable; and whether the unemployment that could be reduced in the model corresponds to those real-world aspects of unemployment that lead people to regard it as a social problem. 
The costs of unemployment take two forms. First, there is the lost output, and hence income, that results from productive workers being idle. Labour is the most important input into production, so reducing unemployment has the potential to have a significant effect in generating increased output. ${ }^{7}$ Second, and probably more important, are the social costs of unemployment that can be considerable. A number of studies have shown that a worker who experiences a prolonged spell of unemployment bears considerable health and psychological costs and a depreciation of work skills. ${ }^{8}$ Unemployment also contributes to the degree of income inequality within the country.

When considering these costs of unemployment, it is important to distinguish between the "incidence" and "duration" of unemployment. The former refers to the number of times on average any worker experiences a spell of unemployment; the latter refers to the average length of each of those spells.

It is duration that matters most when considering the costs of unemployment. To illustrate this, consider two extreme hypothetical economies in which the unemployment rate is 10 per cent, one with high-incidence, low-duration unemployment and the other with the reverse. In the first economy, there is very high labour-market turnover with jobs being lost in areas where products are becoming less desired or productivity is low and other jobs being created in high-demand, highproductivity areas. As a result of this turnover, all workers experience several periods of unemployment when moving from one job to another with the result that all workers are unemployed for 10 per cent of their working lives. In the second example, labour-market turnover is very low, but there are structural impediments to achieving full employment. As a result, 90 per cent of workers never experience unemployment and the remaining 10 per cent are unemployed permanently.

In the first economy, the high turnover enables the economy to shift its labour resources quickly to where they are most productive. Over time, the productivity growth enabled by these quick labour shifts will offset and maybe even outweigh the continual lost production that comes from having 10 per cent of the labour force unemployed. In the second economy, however, the

7. As a rough estimate of the relative importance of labour in production, note that between 70 and 75 per cent of net domestic income is payments to labour as wages and salaries, with the remaining 20 to 25 per cent being paid as profits, interest, etc. to all other factors of production including self-employed labour.

8. Jin, Shah, and Svoboda (1995) and Bédard (1996) survey different aspects of the social costs of unemployment. 
10 per cent unemployment represents sheer waste. Similarly, the social costs of unemployment will be very large in the second economy where the burden of unemployment is borne disproportionately by a small group in the labour force. In contrast, when everyone experiences frequent short spells of unemployment, there is no adverse effect on income inequality and the psychological costs of lost self-esteem, etc., are likely to be minor or non-existent.

Of course, neither of these two extreme examples describes the Canadian economy accurately, but they illustrate the importance of considering the effect on unemployment duration when assessing the welfare implications of a policy designed to reduce unemployment. ADP do not address directly the relationship between unemployment and welfare, so it is not clear what is the effect of low inflation on the duration of unemployment in their model. In the model, downward nominal-wage rigidity produces greater job losses at firms that have experienced negative shocks than would have been the case if wages were fully flexible, but it also produces job gains at unconstrained firms who gain market share at the expense of the constrained firms. The net effect of this job destruction and creation is to increase the rate of unemployment by increasing the incidence of unemployment. The effect on duration, however, is ambiguous in their model: by magnifying the degree of job creation and destruction in the economy, low inflation may increase the employment prospects for currently unemployed workers.

Furthermore, since the job destruction caused by downward nominal-wage rigidity is at firms that have suffered negative shocks while job creation is predominantly at firms that have received positive shocks, the net effect of downward nominal-wage rigidity coupled with low inflation is to move employment away from firms in sunset industries and into more productive areas. Thus, in ADP's model, a low-inflation economy is one in which a greater proportion of labour resources is idle at any one time but also one in which the labour that is employed is more productive.

With these offsetting effects between increased unemployment on one hand and increased labour-market turnover and productivity on the other, it becomes an empirical question whether the overall effect of the increased unemployment would be to increase the average duration of unemployment and/or to reduce output significantly. When looking for 
evidence of a long-run causal relationship from low inflation to unemployment due to downward nominal-wage rigidity, it is also important to consider the effect on unemployment duration and output. It is not sufficient simply to assume that any increase in unemployment caused by low inflation corresponds to those aspects of unemployment that are regarded as a serious social problem.

\section{Benefits of low inflation}

Tobin and ADP have identified one potential cost to low inflation operating through downward nominal-wage rigidity, and ADP's model is designed to address this particular issue. The Tobin effect, however, is just one of many possible effects of low inflation. As noted in the introduction, the mainstream view is that there are benefits in the long run to maintaining low and stable inflation. The mechanisms through which low inflation is presumed to generate these benefits are different from the mechanisms of downward nominal-wage rigidity through which ADP suggest low inflation could produce long-run costs. There is no reason why both sets of mechanisms could not be operating simultaneously in the economy, producing both costs and benefits. In order to conclude that it would be desirable to increase the rate of inflation in Canada, one would need to show that the costs outweigh the benefits.

It is beyond the scope of this paper to consider this literature in detail. ${ }^{9}$ There are, however, two potential benefits of low inflation that arise from supposed psychological effects of inflation and that are directly relevant to the question of downward nominal-wage rigidity and thus are worth discussing here.

\subsection{Psychological costs of inflation}

The first psychological effect of inflation concerns "money illusion." In basic economic theory, it is relative prices - that is, the ratios between pairs of prices - that matter for economic outcomes, not the absolute level of prices. A perfect inflation in which all prices, incomes, and the nominal value of all assets rise by the same proportion should have no real economic effect. Consumers are said to suffer from money illusion if inflation does affect their behaviour, due to

9. For surveys of a range of possible costs and benefits of low inflation, see Howitt (1990), Summers (1991), and Konieczny (1994). 
their having difficulty distinguishing clearly between a change in relative prices and a general increase in all prices. If consumers suffer from money illusion, inflation can produce suboptimal decisions by consumers by confusing them about the true nature of changes in relative prices.

A classic example of this concerns saving for retirement. When inflation is positive, part of the nominal interest that people receive on their savings is simply making up for the reduced real value of the money they have saved. If savers suffer from money illusion, they are likely to overestimate the real value of the interest they are receiving and so save less than is needed to sustain a particular standard of living in their retirement. Even a small overestimate of the real interest rate could lead to a substantial error when summed over the 30 or more years of retirement saving. The existence of money illusion, then, is a strong argument in favour of seeking low inflation.

The second psychological effect of inflation is the direct irritation cost it imposes on people. Although economists may disagree about the long-term costs of inflation, there is less disagreement in the broader population: surveys show that distaste for inflation is greater among the general public than it is among economists. (See, for example, Shiller 1996.) If inflation is disliked by people in the economy, then maintaining low inflation is desirable not simply as a means to an end but as an end in itself.

Of course, such surveys are subject to the same critique as the sociological surveys on nominal-wage rigidity: without knowing the exact context assumed by those being surveyed when giving their responses, it is difficult to draw strong policy conclusions from such evidence. The dislike of inflation may simply be due to a form of money illusion in which consumers credit any increase in wages to their own talents or good fortune but blame inflation for the increase in prices of the goods that they purchase.

It is possible, however, that consumers' dislike of inflation represents something real: namely that inflation increases the psychic costs of decision-making. One of the roles of money is to serve as a "unit of account;" that is, rather than prices and wages being quoted in terms of other goods, they are expressed in terms of the monetary unit. This greatly simplifies decision-making, as it means that consumers can simply compare the value they 
expect to get from a good to the value they place on the dollars required to pay for the good. Since the value of money comes in the goods and services it can purchase, the usefulness of using money as a unit of account depends on the consumer having a reasonable sense of the value of a given amount of money in terms of its purchasing power. If inflation keeps reducing the real value of money, the consumer loses this "nominal anchor" against which all prices can be compared. Any consumer who has travelled overseas and finds herself always converting local prices back into her home currency before deciding whether to make a purchase certainly appreciates the value of a nominal anchor.

\subsection{Psychological costs and downward nominal-wage rigidity}

Economists tend to be uncomfortable with arguments that appeal to seemingly irrational psychological effects such as money illusion or dependence on a nominal anchor, since almost anything can be explained in terms of unobservable psychological motivations. The whole idea of downward nominal-wage rigidity, however, rests on the idea that there is a psychological effect that leads to workers' viewing nominal-wage reductions when inflation is very low as being somehow different from an equivalent real-wage reduction brought about purely by inflation.

One view is that downward nominal-wage rigidity is simply money illusion; that is, inflation has an effect because it fools some workers into accepting real-wage reductions to which they would not otherwise agree. It might seem strange that a policy that had an effect by fooling people into making decisions they would not otherwise make could be beneficial. The benefit from mistakes in ADP's model arises because the wage-rigidity argument against low inflation assumes that the interests of a single worker are opposite to those of the economy overall. Specifically, any worker would like the highest real wage he could obtain conditional on retaining employment, whereas the Tobin/ADP framework is predicated on the notion that it would be good for the economy overall to lower real wages. Inflation is then considered desirable as it fools workers into accepting lower real wages.

As laid out in the previous two sections, it remains an open question at this stage whether an inflation-induced lowering of real wages would have the socially beneficial effects postulated by ADP. Moreover, the majority of economic decisions do not have this effect that what is good for the individual is bad for the economy. The main reason for letting private markets be the dominant 
institution for organizing a modern economy is the belief that the well-being of people is best served by letting them make their own decisions about which goods they wish to purchase, which skills they wish to acquire, and so on, based on each individual's own information about his or her own preferences and aspirations. If inflation can fool people into making "desirable" mistakes when actions individually desirable are nevertheless socially costly; it can just as easily fool them into making socially costly mistakes when the interests of the individual and society are not opposed, as in the above example of saving for retirement. To the extent that downward nominal-wage rigidity is evidence of money illusion, it may then actually strengthen the argument in favour of low inflation.

Alternatively, downward nominal-wage rigidity need not imply that people are fooled by inflation so much as they use the nominal anchor of money to help them make decisions about what goods to buy and sell, rather than seeing everything in terms of relative prices. Again, however, this suggests a benefit to low inflation by preserving the nominal anchor that consumers appear to value.

Whatever the reason for it, if downward nominal-wage rigidity is pervasive in the economy, then its existence suggests that there is an important psychological difference between low and moderate inflation. Accordingly, along with spurring interest in the mechanisms outlined in the preceding sections by which low inflation may impose costs on the economy, downward nominal-wage rigidity also forces economists to take the psychological arguments in favour of low inflation more seriously than they have been wont to do.

\section{Conclusion}

An important policy debate in many countries addresses whether it would be desirable to reduce inflation to low levels and then direct monetary policy towards maintaining low and stable inflation. The conventional wisdom in macroeconomics is that there are long-run benefits to an economy in maintaining low rather than moderate or high inflation, but that there are short-run costs from effecting the transition to low inflation from higher levels. Countries experiencing moderate or high rates of inflation have to decide whether the long-run benefits of low and stable inflation outweigh the short-run 
costs of the initial disinflation. For a country like Canada that has already achieved low and stable inflation, however, the short-run costs have already been incurred and so the obvious policy conclusion is to continue the low-inflation policy and enjoy the long-run benefits.

ADP present a major challenge to this conventional wisdom, as they suggest reasons why there may be a long-run trade-off between inflation and unemployment. In their view, the costs of maintaining low inflation are not transitional but ongoing. The policy conclusion for Canada from their analysis would be that the Bank of Canada should reverse its current monetary policy and seek to target higher rates of inflation than the midpoint of the current range of 1 to 3 per cent, as advocated by Fortin (1996a; 1996b).

At this stage, however, ADP's proposition about long-run costs of low inflation due to downward nominal-wage rigidity is very much a conjecture. There remains uncertainty whether downward nominal-wage rigidity is and will continue to be a significant constraint on wage setting, whether that downward nominal-wage rigidity leads to higher unemployment, and whether that increased unemployment produces welfare costs that outweigh other benefits of low inflation. A number of studies have sought to check the empirical importance of downward nominal-wage rigidity but the other key steps in ADP's analysis also need to receive careful attention.

Moreover, even if each of the steps in ADP's analysis could be verified empirically, it would not automatically follow that it would be desirable for Canada to re-inflate. One would have to ask if there were alternative policies that could deal with the labour-market phenomena driving ADP's results. ADP's conclusions are predicated on the assumption that unemployment is caused by excessive real wages and that, because of downward nominal-wage rigidity, inflation is a policy tool that can be used to reduce real wages. This raises the obvious question: if it were considered desirable to reduce real wages, would there be alternative policies that could be used to bring that about?

It may also be possible for policymakers to deal with downward nominal-wage rigidity directly. For example, workers could be encouraged to receive part of their wages as profit shares. A decade ago, Martin Weitzman (1984) wrote about the benefits that could result if a large proportion of firms were to adopt some measure of profit sharing in their wage contracts. Weitzman recommended that the government provide tax incentives to firms to adopt share 
contracts. His concern was rigidity in real wages, but his prescription would apply equally well to problems brought about by rigidity in nominal wages. If downward nominal-wage rigidity is prevalent in labour markets, it might be worthwhile re-examining Weitzman's suggestion.

In summary, most economists would agree that at least part of the sluggish performance of the Canadian economy in the last six years can be attributed to the transitional costs of reducing inflation to its current low levels. Before accepting the proposition that Canada should now re-inflate, thus guaranteeing that those short-run costs were incurred for no benefit, it is important that each of the steps in ADP's analysis be carefully examined, along with possible alternative policy responses. The aim of this paper has been to stimulate debate along these lines. 
Figure 1: Distribution of Canadian Wage Settlements

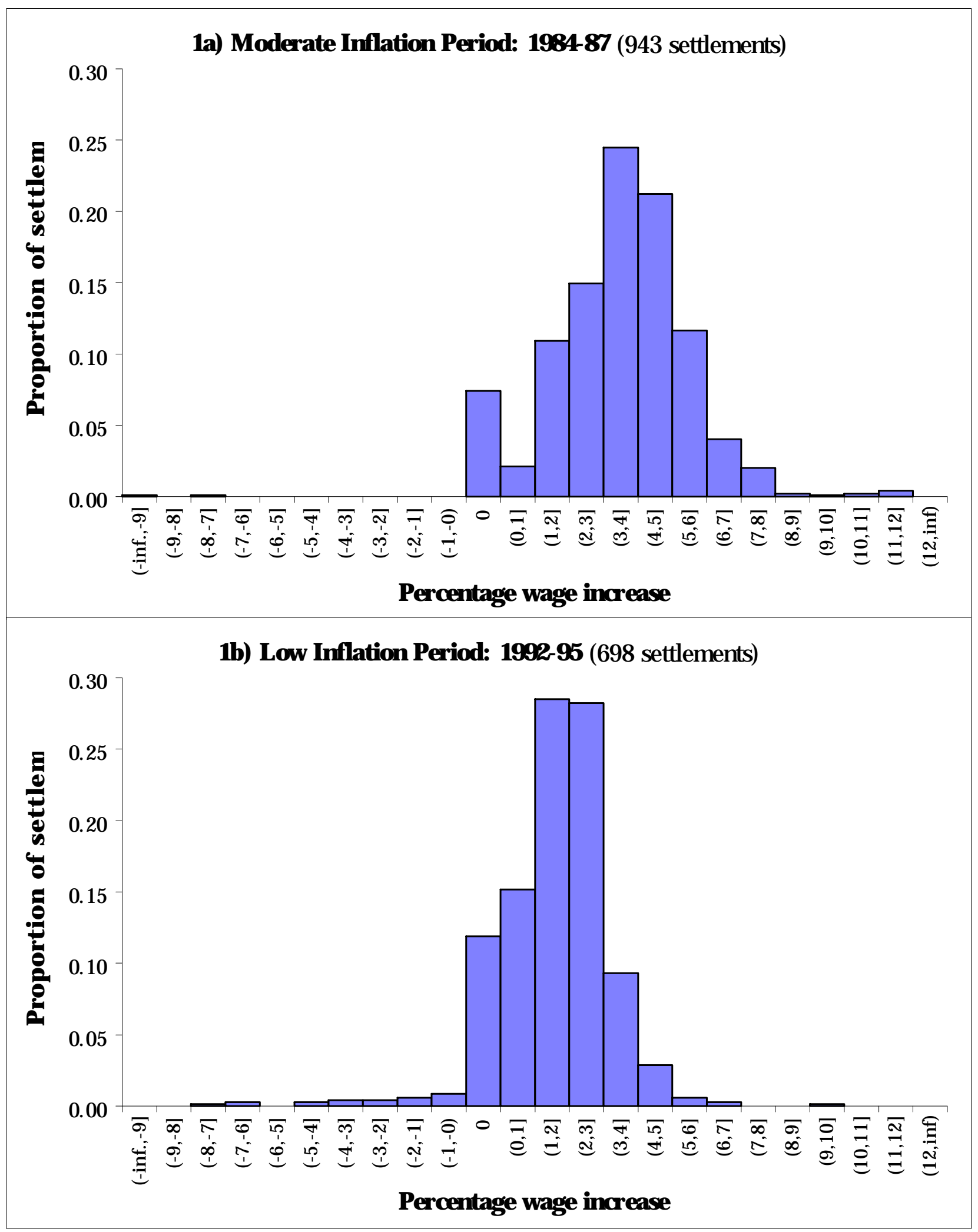

Notes:

Data represents private-sector, unionised, contracts at employers with at least 500 employees.

The percentage wage increase is measured as the average annual increase over the lifetime of the contract. Source: Human Resources Development Canada. 
Figure 2: Hypothetical Wage-Change Distribution (correcting for downward rigidity)

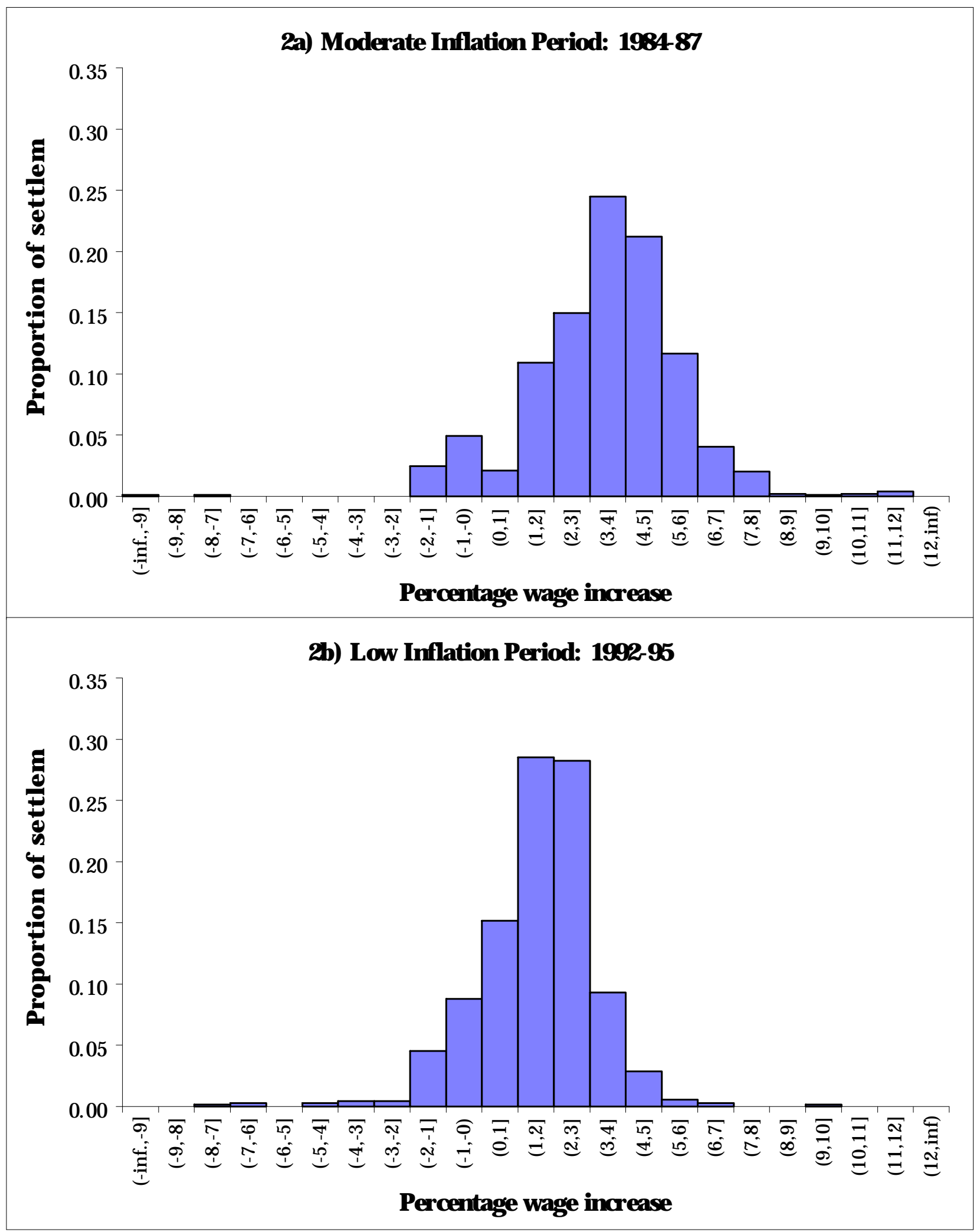


Figure 3: Hypothetical Wage-Change Distribution (correcting for symmetrical rigidity)

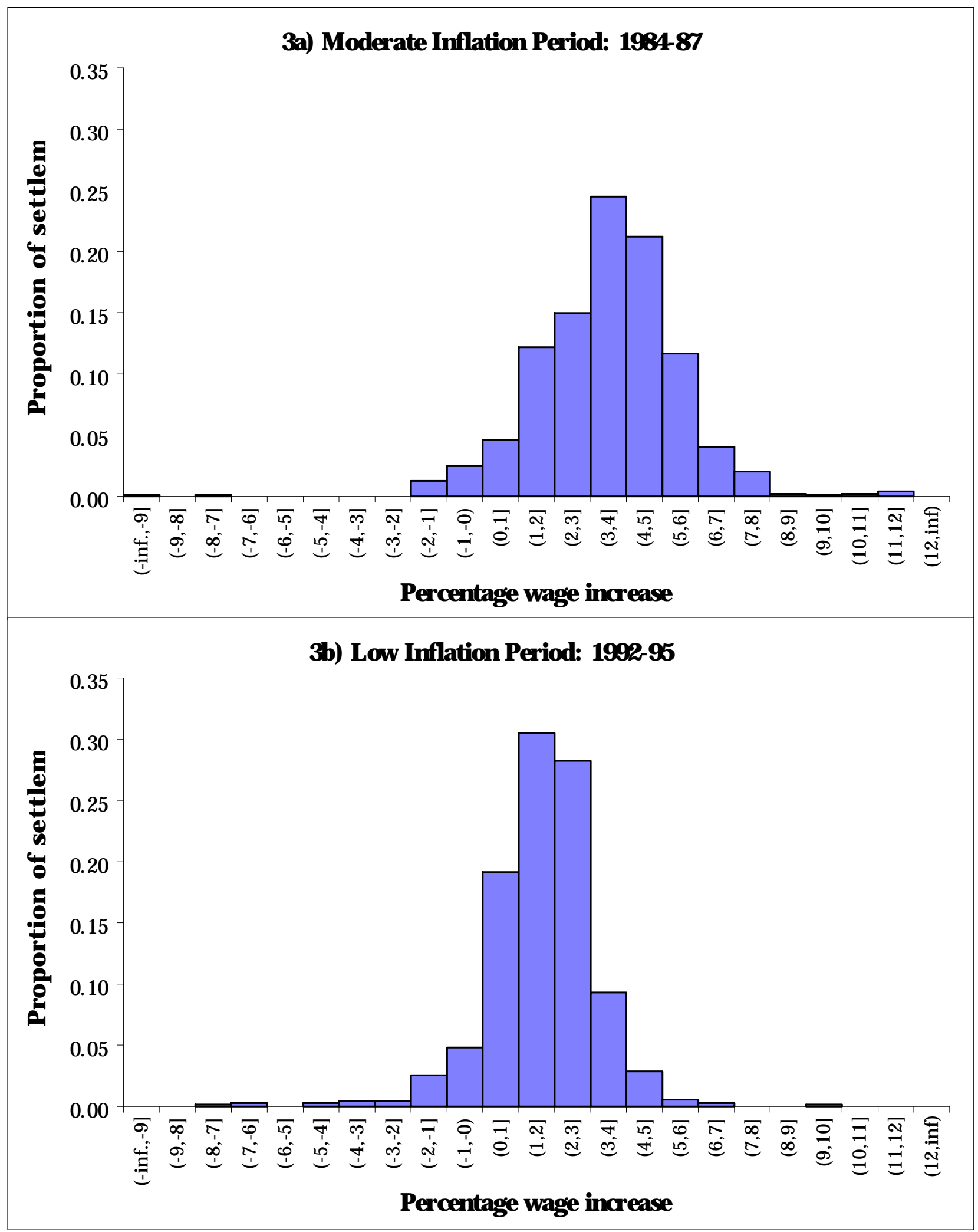




\section{References}

Akerlof, G., W. Dickens and G. Perry. 1996. "The Macroeconomics of Low Inflation." Brookings Papers on Economic Activity 1:1996.

Baldwin, J. and P. Gorecki. 1990. "Structural Change and the Adjustment Process: Perspectives on Firm Growth and Worker Turnover." Economic Council of Canada.

Ball, L. and G. Mankiw. 1994. "Asymmetric Price Adjustment and Economic Fluctuations.” Economic Journal 104: 247-61.

Bédard, M. 1996. “The Economic and Social Costs of Unemployment.” Human Resources Development Canada Working Paper R-96-12.

Bernanke, G. and M. Parkinson. 1991. "Procyclical Labor Productivity and Competing Theories of the Business Cycle: Some Evidence from Interwar U.S. Manufacturing Industries." Journal of Political Economy 99 (3): 439-59.

Bewley, T. 1995. “A Depressed Labor Market As Explained By Participants.” American Economic Review (Papers and Proceedings) 85 (2): 250-4.

Blinder, A. S. and D. H. Choi. 1990. "A Shred of Evidence on Theories of Wage Stickiness." Quarterly Journal of Economics 1003-15.

Card, D. and D. Hyslop. 1996. “Does Inflation 'Grease the Wheels of the Labour Market'?” NBER Working Paper 5538.

Card, D. and A. Krueger. 1995. Myth and Measurement: The New Economics of the Minimum Wage. Princeton, NJ: Princeton University Press.

Davis, S., J. Haltiwanger, and S. Schuh. 1996. Job Creation and Job Destruction. Cambridge, MA: MIT Press.

Devine, T. and N. Kiefer. 1991. Empirical Labour Economics: The Search Approach. Oxford: Oxford University Press.

Fortin, P. 1996a. "Raise the Inflation Target and Let Canada Recover." The Globe and Mail, September 26.

Fortin, P. 1996b. "The Great Canadian Slump." Canadian Journal of Economics 29 (3): 761-87.

Howitt, P. 1990. "Zero Inflation as a Long-Term Target for Monetary Policy." In Zero Inflation: The Goal of Price Stability, edited by R. Lipsey, 67-108. Toronto: C.D. Howe Institute. 
Jin, R. L., C. P. Shah, and T. J. Svoboda. 1995. “The Impact of Unemployment on Health: A Review of the Evidence." Canadian Medical Association Journal 153 (5): 529-540.

Kahn, S. 1995. "Evidence of Nominal Wage Stickiness from Micro-Data." Boston University, School of Management.

Kahneman, D., J. Knetsch and R. Thaler. 1986. "Fairness as a Constraint on Profit Seeking: Entitlements in the Market." American Economic Review 76 (4): 728-41.

Konieczny, J. 1994. "The Optimal Rate of Inflation: Competing Theories and Their Relevance to Canada." In Economic Behaviour and Policy Choice Under Price Stability, 1-40. Ottawa: Bank of Canada.

Krugman, P. 1996. "Stable Prices and Fast Growth: Just Say No.” The Economist, August 31.

Lebow, D., D. Stockton and W. Wascher. 1995. "Inflation, Nominal Wage Rigidity, and the Efficiency of Labor Markets." Finance and Economics Discussion Series 95-45. Washington: Board of Governors of the Federal Reserve System, Division of Monetary Affairs.

McLaughlin, K. 1994. “Rigid Wages?” Journal of Monetary Economics 34 (3): 383-414.

Mankiw, G. 1985. "Small Menu Costs and Large Business Cycles: A Macroeconomics Model of Monopoly." Quarterly Journal of Economics 100 (2): 529-39.

Shiller, R. 1996. “Why Do People Dislike Inflation?” Cowles Foundation Discussion Paper No. 1115.

Summers, L. 1991. "How Should Long-Term Monetary Policy be Determined?” Journal of Money Credit and Banking 23: 625-631.

Tobin, J. 1972. "Inflation and Unemployment." American Economic Review 62 (1): 1-18.

Weitzman, M. 1984. The Share Economy: Conquering Stagflation. Cambridge MA: Harvard University Press. 


\section{Bank of Canada Working Papers}

1997

97-1 Reconsidering Cointegration in International Finance:

Three Case Studies of Size Distortion in Finite Samples

M.-J. Godbout and S. van Norden

97-2 Fads or Bubbles?

H. Schaller and S. van Norden

97-3 La courbe de Phillips au Canada: un examen de quelques hypothèses

J.-F. Fillion and A. Léonard

97-4 The Liquidity Trap: Evidence from Japan

I. Weberpals

97-5 A Comparison of Alternative Methodologies for

Estimating Potential Output and the Output Gap

C. Dupasquier, A. Guay

and P. St-Amant

97-6 Lagging Productivity Growth in the Service Sector:

Mismeasurement, Mismanagement or Misinformation?

D. Maclean

97-7 Monetary Shocks in the G-6 Countries: Is There a Puzzle?

B. S.C. Fung and M. Kasumovich

97-8 Implementation of Monetary Policy in a Regime with Zero Reserve Requirements $\quad$ K. Clinton

97-9 Mesures du taux d'inflation tendenciel T. Laflèche

97-10 The Structure of Interest Rates in Canada:

Information Content about Medium-Term Inflation J. Day and R. Lange

97-11 A Band-Aid Solution to Inflation Targeting R. Amano, R. Black, and M. Kasumovich

97-12 A Micro Approach to the Issue of Hysteresis in Unemployment::

Evidence from the 1988-1990 Labour Market Activity Survey G. Wilkinson

97-13 What Does Downward Nominal-Wage Rigidity Imply for Monetary Policy? S. Hogan

\section{6}

96-13 Speculative Behaviour, Regime-Switching and Stock Market Crashes S. van Norden and H. Schaller

96-14 L'endettement du Canada et ses effets sur les taux d'intérêt réels de long terme J.-F. Fillion

96-15 A Modified P*-Model of Inflation Based on M1 J. Atta-Mensah

Earlier papers not listed here are also available.

Single copies of Bank of Canada papers may be obtained from

Publications Distribution, Bank of Canada, 234 Wellington Street Ottawa, Ontario K1A 0G9

E-mail: publications@bank-banque-canada.ca

WWW: http://www.bank-banque-canada.ca/

FTP: $\quad$ ftp.bank-banque-canada.ca (login: anonymous, to subdirectory

/pub/publications/working.papers/) 